DOI $10.14746 /$ ssp.2015.1.8

\author{
Paweł ANTKOWIAK, Łukasz SCHEFFS
}

Uniwersytet im. Adama Mickiewicza w Poznaniu

\title{
Nowy wymiar przywództwa politycznego: w poszukiwaniu perspektywy do badań personalizacji polityki na poziomie lokalnym ${ }^{1}$
}

\begin{abstract}
Streszczenie: Wizerunek polityka jest szczególnego rodzaju wyobrażeniem ukształtowanym w umyśle wyborców, które wywołując określone skojarzenia - staje się źródłem postaw i wpływa na preferencje wyborcze. Jednocześnie obserwuje się rosnące znaczenie spostrzeganych przez wyborców cech osobowości i wizerunku polityków. Jednym ze skuteczniejszych narzędzi badania podstaw personalizacji polityki, również na poziomie lokalnym, pozostają studia empiryczne nad osobowością polityków. Dotyczyć one powinny pomiaru spostrzeganych przez obywateli cech osobowości polityków. Artykuł jest próbą usystematyzowania pojęć oraz wstępem do przeprowadzenia zaawansowanych badań empirycznych.
\end{abstract}

Słowa kluczowe: personalizacja polityki, wizerunek polityka, polityka lokalna, przywództwo polityczne

\section{Przywództwo na poziomie lokalnym}

Tajogólniej rzecz ujmując, przywództwo, dodajmy polityczne, to wpły1 wanie na zachowania innych (Holly, 1979, s. 459; Iwanek, 2004, s. 110). Równie często podkreśla się jednak takie stanowisko, w którym przywództwo utożsamiane jest z umiejętnością wyzwalania siły do działania umożliwiającego dążenie do wyznaczonego celu (Legutko-Kobus, 2011, s. 126). Z perspektywy samorządu terytorialnego ${ }^{2}$, który pragniemy

1 Wynagrodzenie autorskie sfinansowane zostało przez Stowarzyszenie Zbiorowego Zarządzania Prawami Autorów Twórców Dzieł Naukowych i Technicznych KOPIPOL z siedzibą w Kielcach z opłat uzyskanych na podstawie art. 20 oraz art. $20^{1}$ ustawy o prawie autorskim i prawach pokrewnych.

2 Wśród bogatej mozaiki perspektyw badawczych i podejść teoretycznych na potrzeby tego opracowania poprzestaniemy na ujęciu samorządu terytorialnego jako prerogatyw i zdolności społeczności lokalnej, w granicach określonych prawem, do kierowania i zarządzania zasadniczą częścią spraw publicznych na własną odpowiedzialność i w interesie 
uczynić kanwą całego wywodu, doprecyzować należy, że pojęcie przywództwa obejmuje trzy aspekty możliwych rozważań: terytorialny, podmiotowy oraz przedmiotowy. Aspekt terytorialny wprost dotyczy lokalnych jednostek samorządu terytorialnego, w tym przede wszystkim gmin i powiatów. W sensie podmiotowym przywództwo utożsamiane jest z przedstawicielami organów stanowiących oraz wykonawczych, wybieranych w sposób pośredni lub bezpośredni. Z kolei aspekt przedmiotowy nierozerwalnie związany jest z materią stricte polityczną (Michałowski, 2008, s. 27-28). W swoich rozważaniach poprzestaniemy jedynie na aspekcie podmiotowym tego zjawiska.

Znowu bez wikłania się w zbędne dywagacje teoretyczne dotyczące przywództwa, także na poziomie lokalnym, ustępując pod naporem lawinowo przyrastającej w tym zakresie literatury (Babiak, 2008, s. 87-97; Tomczak, 2011, s. 187-204; Turska-Kawa, 2013a, s. 131-152; Turska-Kawa, 2013b, s. 49-76), swoje poszukiwania pragniemy skoncentrować na nowym - w naszym przekonaniu - sposobie postrzegania miejsca, roli i znaczenia przywódcy w samorządzie. Te przemiany zaś utożsamiamy wprost z ciagłym wzrostem znaczenia marketingu politycznego i nieustannej profesjonalizacji wszelkich działań także w obrębie polityki lokalnej (Sielski, 2012, s. 54).

W opracowaniach szeroko traktujących o przywództwie w samorządzie coraz częściej pojawiają się sugestie dotyczące postępujących w wielu krajach procesach przemian, znajdujących odzwierciedlenie także w zmianach formalnych pozycji np. burmistrza miasta. Wskazuje się przy tym na „modę” na przeprowadzanie bezpośrednich wyborów włodarzy gmin i miast (Ptak, 2010, s. 143-152). Tak właśnie było w Polsce, kiedy przyjęcie ustawy z dnia 20 czerwca 2002 roku o bezpośrednim wyborze wójta, burmistrza i prezydenta miasta (Ustawa) wywołało spore zamieszanie na lokalnej scenie politycznej. Wprowadzono bowiem, na szczeblu podstawowym samorządu, zasadę bezpośredniego wyboru jednoosobowego organu wykonawczego. Wcześniej w gminach mieliśmy do czynienia $\mathrm{z}$ kolegialnym organem wykonawczym wybieranym pośrednio przez organ stanowiący (Antkowiak, 2011, s. 41-42). Tymczasem przeprowadzona zmiana w bardzo wyraźny sposób wzmocniła pozycję organu wykonawczego w gminie ${ }^{3}$. Stanowiska prezydentów dużych miast stały się

mieszkańców. Innymi słowy, w tym rozumieniu samorząd to przede wszystkim prawo i zdolność społeczności lokalnej, a nie instytucji (Regulski, 2010, s. 2).

${ }^{3}$ Mamy zatem silny organ wykonawczy, pochodzaç z bezpośredniego wyboru, który posiada bardzo szeroki wachlarz kompetencji. Nowa pozycja ustrojowa wójta 
bardzo atrakcyjne dla pierwszoplanowych polityków ogólnopolskiej sceny politycznej. Przykładowo Prezydenta Warszawy stawia się na piątym miejsce w kraju, zaraz po Prezydencie RP, premierze oraz marszałkach Sejmu i Senatu (Antkowiak, 2010, s. 157-158).

Zdaniem projektodawców tego pomysłu, bezpośredni wybór organu wykonawczego w gminie, powinien był uatrakcyjnić wybory samorządowe $^{4}$. W toku dyskusji nad ustawą o bezpośrednim wyborze organu wykonawczego w gminie część dyskutantów wskazywała na konsekwencje o charakterze społecznym (Grzesik-Robak, 2004, s. 38) takiego rozstrzygnięcia. Uważano, iż tego rodzaju sposób wyboru włodarza gminy wykreuje nowe kadry samorządowe i będzie elementem profesjonalizacji samorządowej administracji publicznej. Uważano, iż pozwoli to odpartyjnić czy też odpolitycznić zarządzanie w administracji, będąc zarazem nowym, lepszym kanałem awansu politycznego dla zaangażowanych społecznie i politycznie ludzi. Sądzono również, że bezpośrednie wybory władzy wykonawczej będą sprzyjać utożsamianiu się obywateli z władzą samorządową, podnosząc prestiż społeczny funkcjonariuszy publicznych, co poniekąd rzeczywiście miało miejsce (Antkowiak, 2012, s. 77-78).

Opisane powyżej zmiany miały jednak o wiele bardziej znaczące konsekwencje, i to także dla prowadzonych dociekań naukowych. Otóż

jest bardzo silna, w szczególności ze względu na fakt, że bardzo trudno jest odwołać ten organ. W praktyce bowiem bardzo często dochodzi do starć politycznych na linii rada gminy-wójt. Wygenerowano mianowicie konfliktogenną sytuację, która przypomina stan, w którym rząd państwowy nie posiadałby odpowiedniego zaplecza parlamentarnego i próbował skutecznie rządzić. W literaturze przedmiotu rozwiązanie ustawowe, które funkcjonuje aktualnie w Polsce poddawane jest krytyce. Zarzuca się mu m.in. to, że w małych gminach mamy do czynienia z „wójtami dynastycznymi” nie dlatego, że są tak dobrzy w tym co robią, ale dlatego że dzięki swoim uprawnieniom są w stanie piastować władzę w zasadzie bez ograniczeń, przygotowując sobie grunt pod kolejną reelekcję. Wydaje się też, że chęć pozbawienia szans na uczestnictwo we władzach samorządowych osób niezwiązanych z ogólnokrajowymi frakcjami i koteriami politycznymi przeważyła nad potrzebą istnienia stabilnie i konstruktywnie funkcjonującego samorządu (Chmielnicki, 2004, s. 12-23; Chmielnicki, Płażek, 2007, s. 55).

${ }_{4}$ Pierwsze wybory samorządowe, w których Polacy prócz radnych trzech szczebli samorządowych wybierali w wyborach bezpośrednich włodarzy wsi oraz miast odbyły się w dniach 27 października oraz 10 listopada 2002 roku. Frekwencja wyborcza była zaskakująco niska, bowiem wyniosła zaledwie $44,33 \%$. W drugiej turze wyborów organu wykonawczego frekwencja była jeszcze niższa i łącznie spadła do poziomu $35 \%$. Warto jednocześnie powiedzieć, że najniższą frekwencję zanotowano w wyborach prezydentów miast $-29 \%$, nieco wyższą burmistrzów $-38 \%$ oraz najwyższą wójtów - 44,33\%. 
tradycyjne badania polityki lokalnej, skoncentrowane na opisie wpływu poszczególnych aktorów na podejmowane w obrębie samorządu decyzje okazały się niewystarczające. W chwili obecnej uzupełniają je m.in. rozważania teoretyczne oraz badania empiryczne na temat stylów przywództwa w samorządzie lokalnym (Swianiewicz, Klimska, 2003, s. 17).

Dla nas punktem wyjścia do podobnych, ale nie tożsamych dociekań jest założenie, zgodnie z którym bezpośrednie wybory na poziomie lokalnym zaczęły być wiązane z koniecznością kreacji wizerunku ${ }^{5}$ lokalnego polityka, który sprawuje lub ubiega się o władzę (Piechota, Ratajczak, 2012, s. 42). Powołując się na ustalenia Dariusza Skrzypińskiego przyjmujemy, że współcześnie politycy, a tym bardziej ich wizerunki, stają się - także w obrębie aktywności lokalnej - produktem oferowanym na swoistym rynku, który można zdefiniować jako ogół relacji natury prawnej, materialnej i symbolicznej (w tym przede wszystkim komunikacyjnej), zachodzących pomiędzy podmiotami procesów wymiany w przestrzeni społecznej, wyznaczonej przez system polityczny (Skrzypiński, 2011, s. 65).

Z jednej strony stoimy bowiem na stanowisku, że współcześnie (w systemie liberalno-demokratycznym) jesteśmy świadkami dewaluacji takich pojęć, jak polityka, partie polityczne, wybory oraz politycy, liderzy, przywódcy. Zjawisko to zapewne związane jest z kryzysem, nie tylko ekonomicznym, ale i kryzysem przywództwa i związanym z nim kryzysem samej polityki (du Vall, Walecka-Ryduch, 2010, s. 75). Z drugiej zaś strony uznajemy, że szerokie zastosowanie marketingu politycznego, który obecnie nierozerwalnie związany jest z działalnością polityczną powoduje, że przywódca staje się coraz częściej jedynie wyrazicielem poglądów i postaw swoich zwolenników, spełniając przy tym funkcje wyznaczone mu przez system. Co więcej, tego rodzaju przywódca wypełnia powierzone zadania dopóty, dopóki jego zwolennicy uznają go za osobę, która dobrze sprawdza się w swojej społecznej roli (Żukiewicz, 2012, s. 19). Innymi słowy, przywódca w systemie liberalno-demokratycznym (także na poziomie lokalnym) nieustannie zmuszony jest do zabiegania o przychylność wyborców, celem utrzymania społecznego poparcia zarówno w czasie rywalizacji o władzę, jak i podejmowania decyzji władczych (Potocki, 2010, s. 81).

5 Samo pojęcie wizerunku funkcjonuje w naukach społecznych mniej więcej od lat 20. XX wieku. Wprost łączy się je z innym terminem, tj. opinią publiczną i wewnętrznymi wyobrażeniami odbiorców (właśnie opinii publicznej) dotyczącymi spraw publicznych. Co ciekawe, te wyobrażenia są najczęściej zdeformowane i sfragmentaryzowane (Młynarska, 2011, s. 144). 
Uwzględniając co powyżej, przychylamy się do opinii, jakoby ogólna tendencja w rywalizacji na współczesnej scenie politycznej sprowadzała grę wyborczą do pojedynku osobowości, coraz rzadziej natomiast koncentracji na sposobie rozwiązywania określonych problemów. Powoduje to, że wizerunek współczesnego polityka czy kandydata, staje się tak samo ważny, jeśli nie ważniejszy, niż jego poglądy, czy proponowane rozwiązania określonych problemów społecznych (Gierczak, Ostasz, 2009, s. 37-45; Leszczuk-Fiedziukiewicz, 2010, s. 142-198; Zaręba, 2012, s. 75-93). To przybliża nas z kolei do twierdzenia, że obecnie spójne i wyraziste przywództwo na szczeblu regionalnym wymaga istnienia dobrze przygotowanych do pełnienia tej roli polityków (osób). Stąd zaś już tylko krok by stwierdzić, że na poziomie lokalnym coraz wyraźniej dostrzec można, szeroko zoperacjonalizowany na poziomie krajowym i ponadnarodowym, postępujący proces personalizacji polityki (Kotras, 2008, s. 92).

Wielu badaczy dostrzega bowiem sygnały świadczące o ewolucji znaczenia poszczególnych ogniw komunikacji politycznej. Bardzo wyraźna staje się właśnie zmiana pozycji samego lidera partyjnego na rynku politycznym w ramach działań podejmowanych przez niego i partię, z której kandyduje. Do głównych, znaczących zmian zalicza się „substancjonalne" przeniesienie symboliki partyjnej na rzecz wizerunku przywódcy politycznego (polityka, szefa jednostki administracji publicznej, w tym także wójta, burmistrza, czy prezydenta miasta), tendencje do etykietowania poszczególnych rządów nazwiskami członków gabinetów, a także wzrost zainteresowania mediów masowych osobami publicznymi. W ślad za tym rośnie przekonanie, iż wizualna prezentacja kandydatów politycznych staje się kluczowym elementem komunikacji w polityce (Kinastowska, 2013, s. 112).

Wzrost znaczenia przywódców, ich wizerunków i sposobu postrzegania ich cech przez obywateli, a co za tym idzie skoncentrowanie na nich uwagi mediów na tyle ukształtowały współczesne życie polityczne, że obecnie bez ich wypowiedzi publicznych trudno wyobrazić sobie samo uprawianie polityki. Nie powinno więc dziwić, że w takich warunkach życia politycznego partie coraz częściej zatracają swoją tożsamość ideologiczną, która jeszcze do niedawna stanowiła podstawowy punkt odniesienia dla wielu wyborców. Można nawet zaryzykować tezę, że silna pozycja przywódcy (faktyczna lub wykreowana na potrzeby współczesnej działalności politycznej) określa w subiektywny sposób hierarchię wartości, odsuwając na dalszy plan związek danego ugrupowania z wyznawanym przez jego członków i sympatyków światopoglądem (Górka, 2012, s. 220). 


\section{Personalizacja polityki}

Wciąż replikowane, choć prawdziwe pozostaje stwierdzenie, że personalizacja polityki stanowi proces złożony i wieloprzyczynowy, który nie może zostać zinterpretowany wyłącznie przez jedno wyjaśnienie (Marciniak, 2013b, s. 27). Istotę tego mechanizmu można natomiast sprowadzić do twierdzenia, że najważniejszym czynnikiem determinującym wyborcze decyzje jest przywódca i jego społeczno-polityczny wizerunek (Peszyński, 2012b, s. 173). Zasadne wydaje się również domniemanie, że o personalizacji, czy też prezydencjalizacji mówić można w kontekście upodabniania się elekcji parlamentarnych do prezydenckich, i to bez jednoczesnych zmian instytucjonalnych $\mathrm{w}$ ramach poszczególnych systemów politycznych (Peszyński, 2013, s. 75-90). Już bezpośrednio wiążąc personalizację z samą rywalizacją wyborczą, względnie zabiegami marketingowymi (Scheffs, 2015b), przyjąć możemy również założenie, zgodnie z którym personalizacja to koncentracja na poszczególnych politykach, zajmujących stanowiska publiczne z jednoczesnym pomijaniem samej zawartości merytorycznej debaty publicznej i wyborczej (Hartliński, 2012, s. 91).

Coraz liczniejsze publikacje, w swej materii dotykające kwestii personalizacji polityki, powielają jednak nie tylko tezę o tym, że przywódca stanowi najbardziej rozpoznawalny symbol partii (Scheffs, 2010a, s. 131-140; Peszyński, 2012a, s. 62), ale także, iż jest to interdyscyplinarne zagadnienie, w ramach którego wyodrębnić można m.in. personalizację na poziomie instytucjonalnym, medialnym oraz zachowań wyborczych elektoratów i polityków (Rahat, Sheafer, 2007, s. 70-72). Będąc świadomi złożoności tego zagadnienia, jak również ogromu perspektyw teoretycznych i ujęć definicyjnych nie zamierzamy szerzej włączać się w dyskusje semantyczne i terminologiczne, związane $z$ tym zagadnieniem ${ }^{6}$. Czyniąc tak, a tym samym uznając za udowodnioną tezę, zgodnie z którą od kilkunastu lat zauważalny jest wzrost znaczenia przywódców na krajowych scenach politycznych, ustępujemy przed argumentem, że wyborcy częściej głosują, kierując się lojalnością i zaufaniem do konkretnej osoby niż ,abstrakcyjnego" ugrupowania. Przychylamy się także do stanowiska, że wiele jest

6 Obszerne omówienie zagadnień związanych nie tylko z podejmowanymi próbami definicyjnymi personalizacji i prezydencjalizacji polityki, ale także ewentualnymi przyczynami zaistnienia tego procesu znajdują się w opracowaniu autorstwa Ł. Scheffsa (Scheffs, 2012, s. 287-304). 
dowodów na przesunięcie się władzy politycznej z rąk organów kolektywnych, takich jak partie oraz parlamenty, w ręce przywódców politycznych (Skiba, 2010, s. 26).

Oczywiście nie oznacza to, że bezwiednie akceptujemy założenie o całkowitej marginalizacji ideologii politycznej, a w konsekwencji programów politycznego działania. Z badań prowadzonych m.in. przez Andrzeja Falkowskiego i Małgorzatę Michalak wynika, że przynajmniej programy wyborcze nadal odgrywają istotne znaczenie w decyzji podejmowanej przez wyborców. Nawet więcej, prowadzone badania kształtowania pamięci wyborców sugerują, że związki przyczynowo-skutkowe percepcji wizerunków polityków przebiegają od oceny programu wyborczego do pozostałych cech wizerunków. Otrzymane przez tę dwójkę badaczy wyniki wskazuja, iż ocena programu wyborczego określa de facto ocenę cech osobowościowych kandydatów. Ci sami autorzy konstatują dalej, że wobec tego w przygotowaniu strategii wyborczych nie można skupić się jedynie na cechach osobowych lub programie wyborczym polityka. Okazuje się, że obydwa te elementy wizerunku kandydata są ze sobą połączone w określonym związku i rozpatrywanie ich niezależnie od siebie może zdecydować o niepowodzeniu kandydata (Falkowski, Michala, 2011, s. 364).

Niezależnie od powyższego nas, zarówno ze względu na własne zainteresowania, jak i planowane badania empiryczne, szczególnie interesuje jednak wybór odpowiedniej perspektywy do badań nad procesem personalizacji polityki. W przeciwieństwie do znanych nam publikacji, nie chcemy jednak zajmować się wpływem personalizacji na przemiany społeczne, kulturowe i oczywiście polityczne. Drugorzędne w tym przypadku jest dla nas także poszukiwanie odpowiedzi na pytanie o przyczyny postępującego wciąż procesu personalizacji. Te zresztą są już dość dobrze zbadane i opisane (Blumler, Kavanagh, 1999, s. 209-230). W naszym przekonaniu ważkie i wciąż niezgłębione pozostaje natomiast zagadnienie personalizacji na poziomie lokalnym (Niklewicz, 2014, s. 2). Ten obszar badań wydaje się nam o tyle kuszący, że w Polsce pierwsze studia nad personalizacją polityki na szczeblu regionalnym pojawiły się całkiem niedawno (Peszyński, 2011; Bukowski, Flis, Hess, Szymańska, 2011).

Dziś jeszcze nie jesteśmy w stanie w sposób jednoznaczny odpowiedzieć na pytanie o zakres projektowanych badań. Z dużą dozą prawdopodobieństwa stwierdzić możemy jednak, że nasze dociekania dotyczyć będą - o czym była już mowa powyżej - aspektu podmiotowego, a dokładniej cech osobowościowych przywódców uwzględnianych przez 
potencjalnych wyborców (Turska-Kawa, 2011, s. 165-186). To ujęcie problematyki spersonalizowanej w Polsce władzy na poziomie lokalnym, w świetle poczynionej przez nas kwerendy, nie doczekało się jak dotąd wnikliwych analiz. Odmiennie ta kwestia wygląda natomiast na poziomie ogólnopolskim, gdzie studia z zakresu wizerunku politycznego i przyczyn wzrostu znaczenia tego aspektu współcześnie uprawianej polityki zyskują wciąż na znaczeniu (Pawełczyk, Jankowiak, 2013, s. 35-43; Marciniak, 2013a, s. 64-74).

W literaturze przedmiotu wskazuje się aż siedem typów personalizacji:

- personalizację instytucjonalną: zmiany instytucjonalne, które za priorytet uznają promowanie indywidualnych polityków;

- skupienie się na politykach: gdy osobowości zyskują uwagę mediów kosztem partii;

- potraktowanie wizerunku przywódcy partyjnego jako uosobienia partii: lider jako główna osobowość partii w ocenie polityków i wyborców;

- indywidualne polityczne kompetencje: indywidualne kompetencje zawodowe szczegółowo oceniane przez media;

- osobiste narracje: osobiste zaplecze i emocje pojedynczych polityków ukazywane przez media;

- prywatyzacja: coraz większe zainteresowanie prywatnym życiem polityków;

- personalizacja zachowań politycznych: tendencja do pomniejszania działalności partii na korzyść jednostkowych zachowań politycznych (Piontek, 2012, s. 114).

Z typologii tej wynika, że kategoria personalizacji jest złożona i obejmuje działania partii, polityków, mediów i wyborców. Na dodatek analiza polskiej literatury przedmioty pozwala na stwierdzenie, że krajowe badania oscylują jedynie w obrębie ujęcia instytucjonalnego, rzadziej behawioralnego.

Aspekt instytucjonalny personalizacji ma związek z samym sposobem konstruowania list wyborczych. Najjaskrawszym tego przykładem są starania związane z lokowaniem na wyborczych listach społecznie popularnych osób, których profil (wizerunek) nie musi być w ogóle zbieżny z platformą programową danej opcji politycznej (Peszyński, 2010, s. 60). Wspomniana ,popularność” przejawia się zresztą w wielu obszarach, np. instytucjonalizacji debat telewizyjnych najbardziej liczących się liderów partii politycznych (Peszyński, 2013, s. 84), czy wprost przyjętej strategii poszczególnych komitetów, ale i zawartością mediów w kampanii wybor- 
czej (Peszyński, 2012b, s. 178; Peszyński, 2012a, s. 64). Wyraz takiemu podejściu do samej rywalizacji wyborczej dano nie tylko przy okazji różnych elekcji krajowych. Ten sposób systemowego podejścia do procesu personalizacji całej polityki ma miejsce - przynajmniej w polskich realiach politycznych - także na poziomie wyborów do Parlamentu Europejskiego (Jędrzejczak, 2009, s. 87-92; Scheffs, 2010b, s 77-90). Dodatkowo pojawiają się opracowania, w których analizie poddawany jest sam sposób konstrukcji list wyborczych, a nade wszystko systemu wyborczego. Niektórzy badacze zwracają uwagę m.in. na wpływ kandydatów na głosowanie, uwzględniając dodatkowo przyjęte w danym kraju rozwiązania systemowe. Dobrym przykładem jest tu głosowanie w mieszanych systemach wyborczych, gdzie o ile wyborca w części proporcjonalnej systemu wyborczego udziela poparcia liście najbardziej przez siebie preferowanego ugrupowania, to w okręgu jednomandatowym popiera już tego kandydata, którego walory indywidualne (np. doświadczenie, zasługi w pracy na rzecz danej społeczności zamieszkującej okręg) przedkłada nad afiliację partyjną oraz szanse na zdobycie mandatu. W ten sposób cechy szczególne kandydata oraz jego osobisty apel skierowany bezpośrednio do elektoratu czynią zeń beneficjenta głosowania (Salamon, 2012, s. 189). Ujęcie behawioralne z kolei oscyluje wokół skutków, jakie w kontekście preferencji głosujących kształtują partyjni przywódcy (Marsh, 2007, s. 502-527).

\section{Spostrzegane cechy osobowości}

W Polsce wizerunek, definiowany choćby jako uproszczony obraz osoby w oczach odbiorcy (Cichosz, 2005, s. 79), niejednokrotnie był już obiektem badań. Dokonywane w trakcie tych prac oceny opierano na bardzo podobnych kryteriach: skuteczności w działaniu, kompetencjach, dbałości o dobro państwa (Scheffs, 2015a). Szybko udoskonalono tego rodzaju empirie, sednem poszukiwań czyniąc nie tyle wizerunek polityka, co raczej profil symboliczny kandydata (Braud, 1995).

Przygotowując tego rodzaju badania wypracowano zestaw typowych cech - stwierdzeń charakteryzujących polityka. W tym zbiorze znalazły się takie pary przeciwstawnych określeń jak: jest przystojny, ma dobrą prezencję - nie jest przystojny, źle się prezentuje; jest inteligentny - nie wyróżnia się inteligencję; jest kompetentny, zna się na tym, co robi - jest niekompetentny, nie ma odpowiedniej wiedzy i umiejętności; mówi kon- 
kretnie, w sposób odpowiedzialny - mówi niejasno, nie wiadomo, co tak naprawdę myśli; jest energiczny, dynamiczny - jest zbyt powolny, mało dynamiczny; jest konsekwentny, stanowczy w osiaganiu swoich celów - nie potrafi dokończyć tego, co zaczął, wszystko „rozłazi mu się w rękach"; rozumie ludzi, troszczy się o ich los - nie obchodzi go los zwykłych ludzi; jest uczciwy, nieprzekupny - tak jak wielu innych „na górze” myśli tylko o swoim własnym interesie (Społeczny, 1996; Cybulska, 1999). Z czasem powyższy katalog uzupełniono i poszerzono o dodatkowe kryteria, m.in. jest sympatyczny - nie jest sympatyczny; jest skromny - jest zarozumiały; jest otwarty na innych - jest nieprzystępny; przedkłada dobro kraju nad własne interesy - dba przede wszystkim o własny interes; potrafi przekonać ludzi do swoich racji - nie potrafi przekonać ludzi do swoich racji; umie stawić czoło najważniejszym problemom, nie boi się trudnych decyzji - uchyla się od rozwiązywania najważniejszych problemów, nie potrafi podejmować trudnych decyzji; jest samodzielny w podejmowani decyzji - nie jest samodzielny w podejmowaniu decyzji, za bardzo daje sobą kierować (Cybulska, 1999).

W pełni profesjonalne badania dotyczące bezpośrednio cech osobowości polityków, a pośrednio personalizacji polityki wypracowano jednak dopiero na gruncie psychologii polityki. Przedstawicieli tej dyscypliny interesowały takie elementy złożonego procesu personalizacji, jak: poziom spostrzegania podobieństw poglądów pomiędzy wyborcami a wybieranymi przez nich politykami, ocena stałości postaw polityków wobec ważnych problemów społeczno-politycznych, porównywanie zgodności między głoszonymi przez polityków poglądami a działaniami, wartościowanie decyzji politycznych w kategoriach sprawiedliwości społecznej oraz opinia dotycząca kompetencji i dbałości o interesy wyborców (Urban, 2001, s. 279).

Punktem wyjścia dla tego rodzaju eksploracji stała się z kolei identyfikacja wyborców z reprezentującymi ich politykami przez pryzmat cech osobowości, a w szczególności - zgodność osobowościowa wyborców i wybranych (popieranych) przez nich polityków. Wyraz takiemu stanowisku dali m.in. Philip G. Zimbardo i Gian V. Caprara, konstruując model zgodności preferencji politycznych. Badacze ci zwrócili uwagę na fakt, że współczesna polityka stała się spersonalizowana ze względu na to, że indywidualne cechy polityków i wyborców znacznie zyskały na znaczeniu w dyskursie politycznym. Samo to znaczenie odzwierciedla się w zachowaniach wyborczych społeczeństwa. Wyborcy często głosują na tych kandydatów, których cechy osobowościowe odpowiadają ich własnym. 
Innymi słowy, to podobieństwo jest czynnikiem poparcia wyborczego. Model zgodności preferencji politycznych zaproponowany i zoperacjonalizowany przez P. G. Zimbardo i G. V. Caprara stanowi, że cechy osobowości przyciagają uwagę wyborców bardziej niż poglądy i programy polityczne, a kandydaci w trakcie kampanii polaryzują stanowiska i podkreślają cechy charakteru, na podstawie których wyborcy mogą zracjonalizować (usprawiedliwić) swój wybór (Caprara, Zimbardo, 2004, s. 581-594).

Rozwinięciem opisanego powyżej paradygmatu stały się badania dotyczące cech osobowości polityków i wyborców. Na ich podstawie udało się ustalić, że ludzie opisują osobowości innych na takich samych wymiarach, na jakich kreują własną osobowość. Niemniej politycy są spostrzegani przez pryzmat ograniczonej liczby wymiarów. Przyczyn redukcji liczby tych wymiarów można upatrywać m.in. w procesie selekcji. Nie jest bowiem wykluczone, że w procesie kreowania wizerunków polityków w ich tożsamości łączy się pewne cechy, które są pożądane przez wyborców. Systematyczne promowanie takich samych wiązek cech może z kolei przekładać się na przekonania wyborców o ich współwystępowaniu w osobowości polityków. Inną możliwą przyczyną redukcji liczby wymiarów percepcji osobowości polityków może być także sam proces spostrzegania. Wyborcy często stosują strategię ekonomii poznawczej. Innymi słowy, posługują się heurystykami (uproszczonymi regułami wnioskowania), radząc sobie w ten sposób z ogromem docierających do nich informacji. Prowadzi to jednak do uformowania się uproszczonego schematu spostrzegania przywódcy politycznego, a także partii, którą on reprezentuje. Nawet więcej, następuje ograniczenie jedynie do cech, które zwiększają prawdopodobieństwo pewnych zachowań polityka, kiedy zostanie wybrany na dane stanowisko (Oleś, 2000, s. 7-18; Hornowska, Kaliszewska, 2003, s. 7-14; Szarota, 2008, s. 127-138; Miluska, 2009, s. 505-521; Strus, Cieciuch, Rowiński, 2011, s. 65-93; Strus, Cieciuch, 2014, s. 17-49).

\section{Podsumowanie}

Reasumując, obecnie wyborcy podejmując decyzje wyborcze, kierują się m.in. wizerunkami polityków i/lub partii w zależności od specyfiki wyborów politycznych. Wizerunek polityka jest szczególnego rodzaju wyobrażeniem ukształtowanym w umyśle wyborców, które wywołując określone skojarzenia - staje się źródłem postaw i wpływa na preferencje wyborcze. Jednocześnie obserwuje się rosnące znaczenie spostrzeganych 
przez wyborców cech osobowości i wizerunków polityków. Przyczyn tego stanu rzeczy jest wiele: wzrost stopnia indywidualizacji decyzji wyborczych, wzrost poziomu wykształcenia wyborców i ich większe zainteresowanie polityką. Wreszcie w warunkach niestabilnego wizerunku formacji politycznych przekonania na temat cech osobowości polityków mogą stanowić kotwicę, wokół której są organizowane informacje na temat osoby polityka, umożliwiające predykcję jego zachowania, w tym ocenę konsekwencji w realizacji obietnic wyborczych (Gorbaniuk, 2009, s. 88-89).

Biorąc pod uwagę dotychczasowe ustalenia stoimy na stanowisku, że jednym ze skuteczniejszych narzędzi badania podstaw personalizacji polityki, również na poziomie lokalnym, pozostają studia empiryczne nad osobowością polityków. Te z kolei można sprowadzić do trzech ogólnych nurtów:

- bezpośredniego pomiaru osobowości polityków;

- pośredniego pomiaru osobowości polityków;

- pomiaru spostrzeganych przez obywateli cech osobowości polityków (Gorbaniuk, 2009, s. 88-89).

W toku naszych poszukiwań właśnie tę ostatnią perspektywę pragniemy uczynić przedmiotem naszego zainteresowania.

Tak podjętą decyzję motywujemy tym, że cechy wykorzystywane najczęściej do rozpoznania siebie stają się narzędziem rozpoznawania innych, i to narzędziem stosunkowo prostym. Dodatkowo cechy te tworzą pewien zinterioryzowany aparat kategorialny, który ułatwia poznanie. W obliczu ubogiego aparatu kategorialnego dotyczącego mechanizmów polityki (również w ramach samorządu terytorialnego) kategorie opisujące cechy polityków uzyskują przewagę. Sprzyjają temu sami politycy, eksponując w toku kampanii raczej cechy osobowości niż programy. Wyborcy z kolei zwracają uwagę na widoczne publicznie charakterystyki polityków i poszukują tych cech, które odpowiadają ich własnym (Marciniak, 2013c, s. 134). Jedyne co nam wobec tego pozostało to przeprowadzenie stosownych badań, a następnie ich prezentacja.

\section{Bibliografia}

Antkowiak P. (2010), Polskie prawo wyborcze $w$ wyborach samorzqdowych - doświadczenia i perspektywy rozwoju, w: Prawo wyborcze i wybory. Doświadczenia dwudziestu lat procesów demokratyzacyjnych w Polsce, red. A. Stelmach, Wydawnictwo Naukowe WNPiD UAM, Poznań. 
Antkowiak P. (2011), Samorzad terytorialny na przykładzie miasta Konina, Wydawnictwo Naukowe WNPiD UAM, Poznań.

Antkowiak P. (2012), Ewolucja samorzqdowej ordynacji wyborczej w Polsce w okresie transformacji systemowej, „Przegląd Zachodni”, nr 1.

Babiak J. (2008), Cechy przywódcze jako determinanty sukcesu organizacyjnego: odradzajacy się kierunek $w$ badaniach przywództwa organizacji, „Przegląd Psychologiczny", nr 1.

Blumler J. G., Kavanagh D. (1999), The Third Age of Political Communication: Influences and Features, „Political Communication”, vol. 16.

Braud P. (1995), Rozkosze demokracji, Wydawnictwo Naukowe PWN, Warszawa.

Bukowski M., Flis J., Hess A., Szymańska A. (2011), Opcja czy osoba? Upartyjnienie versus personalizacja w wyborach samorzadowych, Wydawnictwo Uniwersytetu Jagiellońskiego, Kraków.

Caprara G. V., Zimbardo P. G. (2004), Personalizing Politics. A Congruency Model of Political Preference, „American Psychologist”, vol. 59, nr 7.

Chmielnicki P. (2004), Określenie relacji pomiędzy organami gminy-wybrane zagadnienia, w: Samorzad lokalny w Polsce - spoleczno-polityczne aspekty funkcjonowania, red. S. Michałowski, A. Pawłowska, Wydawnictwo UMCS, Lublin.

Chmielnicki P., Płażek S. (2007), Powszechne wybory wójta (burmistrza, prezydenta miasta): uwagi krytyczne wobec niektórych aspektów obecnej regulacji, „Przegląd Prawa Publicznego", nr 4.

Cichosz M. (2005), Wizerunek lidera politycznego, w: Marketing polityczny. W poszukiwaniu strategii wyborczego sukcesu, red. M. Jeziński, Wydawnictwo Adam Marszałek, Toruń.

Cybulska A. (1999), Społeczny wizerunek prezydenta Aleksandra Kwaśniewskiego, Komunikat z badań, BS/17/99, Centrum Badania Opinii Społecznej, Warszawa, http://badanie.cbos.pl/details.asp?q=a1\&id= 2071, 21.04.2012.

du Vall M., Walecka-Ryduch A. (2010), Kryzys przywództwa w dobie marketingu politycznego, w: „Stare” $i$ „,nowe” media w kontekście kampanii politycznych i sprawowania władzy, red. M. du Vall, A. Walecka-Rynduch, Krakowska Akademia im. Andrzeja Frycza Modrzewskiego, Kraków.

Falkowski A., Michalak M. (2011), Wsteczne kształtowanie pamięci oceny programu wyborczego polityka. Przyczynowa struktura pamięci wizerunku kandydatów, „Psychologia Społeczna”, t. 6, nr 4.

Gierczak A., Ostasz G. (2009), Elementy rodzinne i osobiste w budowaniu wizerunku polityka, ,Zeszyty Naukowe Politechniki Rzeszowskiej”, z. 16.

Gorbaniuk O. (2009), Wymiary dyferencji profili spostrzeganych cech osobowości polskich polityków: analiza danych zastanych, „Psychologia Społeczna”, t. 4, nr $1-2$.

Górka M. (2012), Wybrane problemy metodologiczne $w$ kontekście rywalizacji politycznej w Polsce po 2005 roku, „Studia Gdańskie”, t. 9. 
Grzesik-Robak A. (2004), Bezpośrednie samorzqdowe wybory prezydentów miast 2002 - próba analizy, „Samorząd Terytorialny”, nr 6.

Hartliński M. (2012), Prezydencjalizacja współczesnej polityki, „Szkice Humanistyczne", t. 12, nr 2.

Holly R. (1979), Badania nad przywództwem nieformalnym w małych grupach, „Przegląd Psychologiczny”, t. 22, nr 3.

Hornowska E., Kaliszewska K. (2003), Neurogenetyczna koncepcja osobowości R. C. Cloningera - zwiazki z teoria PEN H. J. Eysencka oraz Model Wielkiej Piqtki w ujęciu P. T. Costy i R. R. McCrae, „Czasopismo Psychologiczne”, t. 9, nr 1.

Iwanek J. (2004), Przywództwo demokratyczne w systemie demokratycznym, w: Przywództwo polityczne. Teorie i rzeczywistość, red. L. Rubisz, K. Zub, Wydawnictwo Adam Marszałek, Toruń.

Jędrzejczak T. (2009), Eurowybory 2009. Personalizacja polityki, „Realia i co Dalej...", nr 4.

Kinastowska J. (2013), Branding personalny $i$ coaching jako techniki zarzadzania marka jednostek administracji publicznej, „Coaching Review”, nr 1.

Kotras M. (2008), Obrazy przywództwa politycznego na poziomie regionalnym, „Acta Universitatis Lodziensis. Folia Sociologica", nr 33.

Legutko-Kobus P. (2011), Rola lidera lokalnego w rozwoju gminy, „,Kwartalnik Kolegium Ekonomiczno-Społecznego Studia i Prace / Szkoła Główna Handlowa”, nr 2.

Leszczuk-Fiedziukiewicz A. (2010), Strategie ocieplania i kontrolowania wizerunku polityka na przykładzie prezydenckiej kampanii wyborczej 2010 r., „Studia Politologiczne", vol. 19.

Marciniak E. M. (2013a), Percepcja cech osobowości Jarosław Kaczyńskiego i Donalda Tuska przez ich zwolenników, „Athenaeum. Polskie Studia Politologiczne”, vol. 39.

Marciniak E. M. (2013b), Personalizacja zachowań wyborczych w Polsce w kontekście Modelu Zgodności Preferencji Politycznych, Dom Wydawniczy ELIPSA, Warszawa.

Marciniak E. M. (2013c), Podobieństwo osobowości wyborców i polityków jako czynnik poparcia wyborczego, „Annales. Universitatis Mariae Curie-Skłodowska Lublin - Polonia", vol. 20, nr 2.

Marsh M. (2007), Candidates or parties? Objects of electoral choice in Ireland, „Party Politics", nr 13.

Michałowski S. (2008), Uwarunkowania petnienia ról przywódczych w samorzadzie terytorialnym, w: Przywództwo lokalne a kształtowanie demokracji partycypacyj$n e j$, red. S. Michałowski, K. Kuć-Czajkowska, Wydawnictwo UMCS, Lublin.

Miluska J. (2009), „Wielka Piatka” a preferencje polityczne, w: Polityka i politycy. Diagnozy - oceny - doświadczenia, red. J. Miluska, Wydawnictwo Naukowe UAM, Poznań. 
Młynarska K. (2011), Zarzadzanie wizerunkiem. Proces kreowania wizerunku, „Studia i Materiały. Miscellanea Oeconomicae", nr 1.

Niklewicz K. (2014), Sposób na wyborce, „Analiza”, Instytut Obywatelski, nr 5.

Oleś P. (2000), Kontrowersje wokót ,, Wielkiej Piątki”, „Czasopismo Psychologiczne”, t. 6 , nr 1-2.

Pawełczyk P., Jankowiak B. (2013), Cechy wizerunku politycznego a emocje w głosowaniu na Bronisława Komorowskiego i Jarosława Kaczyńskiego w wyborach prezydenckich $w 2010$ roku. Raport z badań postaw politycznych studentów, „Przegląd Politologiczny”, nr 2.

Peszyński W. (2011), Kandydat czy partia? W poszukiwaniu determinant zachowań wyborczych elektoratu, „Preferencje Polityczne”, nr 2.

Peszyński W. (2012a), Personalizacja kampanii parlamentarnej w Polsce 2011 roku, „Athenaeum. Polskie Studia Politologiczne”, vol. 35.

Peszyński W. (2012b), Personalizacja politycznych preferencji, „Preferencje Polityczne", nr 3.

Peszyński W. (2013), Prezydencjalizacja zachowań elektoratu w roku „,niewyborczym” 2012, „Preferencje Polityczne”, nr 6.

Piasecki A. (2003/2004), Bezpośrednie wybory 2002 r. Próba syntezy, „Problemy Humanistyki”, $\mathrm{nr} 8 / 9$.

Piechota G., Ratajczak R. (2012), Media samorzqdowe jako narzędzie kreacji wizerunku lokalnego lidera i jego otoczenia, „Athenaeum. Polskie Studia Politologiczne", vol. 34.

Piontek D. (2012), Personalizacja rywalizacji wyborczej w kampanii parlamentarnej, „Rocznik Nauk Społecznych”, t. 4, nr 3.

Potocki P. (2010), Wizerunek przywódcy w systemie totalitarnym, autorytarnym i demokratycznym. Analiza porównawcza, „Economy and Management”, nr 2.

Ptak A. (2010), Ewolucja systemu wyborczego do organów samorzqdu terytorialnego w Polsce, w: Prawo wyborcze $i$ wybory. Doświadczenia dwudziestu lat procesów demokratyzacyjnych w Polsce, red. A. Stelmach, Wydawnictwo Naukowe WNPiD UAM, Poznań.

Rahat G., Sheafer T. (2007), The personalization(s) of politics: Israel 1949-2003, „Political Communication", vol. 24.

Regulski J. (2010), Samorząd a model państwa, „Infos”, Biuro Analiz Sejmowych, nr 10.

Salamon J. (2012), Wpływ kandydatów na głosowanie podzielone w mieszanych systemach wyborczych, ,e-Politikon”, nr 3.

Scheffs Ł. (2010a), Lider polityczny $w$ totalitarnym i demokratycznym systemie politycznym. Pozorna opozycja?, „Refleksje”, nr 2.

Scheffs Ł. (2010b), Polska wideopolityka w wyborach do Parlamentu Europejskiego w 2009 roku, w: Wybory do Parlamentu Europejskiego. Media i marketing 
polityczny, red. M. Jeziński, W. Peszyński, A. Seklecka, Wydawnictwo Adam Marszałek, Toruń.

Scheffs Ł. (2012), Proces personalizacji polityki, w: Komunikowanie spoleczne w badaniach młodych naukowców, red. J. Karwat, Wydawnictwo Naukowe Wyższej Szkoły Handlu i Usług w Poznaniu, Poznań.

Scheffs Ł. (2015a), Personalizacja polityki w świetle wyników badania opinii publicznej. Przeglad wybranych badań (w druku).

Scheffs Ł. (2015b), Socjotechniczne aspekty personalizacja polityki (w druku).

Sielski J. (2012), Przywódcy i liderzy samorzadowi (lokalni), „Prace Naukowe Akademii im. Jana Długosza w Częstochowie”, wydanie specjalne.

Skiba L. (2010), Rzadzić państwem. Centrum decyzyjne rzadu $w$ wybranych krajach europejskich, Instytut Sobieskiego, Warszawa.

Skrzypiński D. (2011), Marketing w lokalnych kampaniach wyborczych: faktyczne czy deklarowane działania liderów, w: Profesjonalizacja i mediatyzacja kampanii politycznych w Polsce, red. K. Churska-Nowak, S. Drobczyński, Wydawnictwo Naukowe Wyższej Szkoły Nauk Humanistycznych i Dziennikarstwa, Poznań.

Społeczny wizerunek premiera Włodzimierza Cimoszewicza (1996), Komunikat z badań, BS/77/76/96, Centrum Badania Opinii Społecznej, Warszawa, http://badanie.cbos.pl/details.asp?q=a1\&id=1581, 21.04.2012.

Strus W., Cieciuch J. (2014), Poza wielka piatke - przeglą nowych modeli struktury osobowości, „Polskie Forum Psychologiczne”, t. 19, nr 1.

Strus W., Cieciuch J., Rowiński T. (2011), Kołowy model struktury cech osobowości w ujęciu Lewisa Goldberga, „Studia Psychologica”, nr 11.

Swianiewicz P., Klimska U. (2003), Kto rzadzi gminq i jak? Lokalni liderzy polityczni w teorii i praktyce samorzadów w Polsce, ,Studia Regionalne i Lokalne”, nr 4.

Szarota P. (2008), Wielka piatka - stare problemy, nowe watpliwości, „Roczniki Psychologiczne", t. 11, nr 1.

Tomczak Ł. (2011), Przywódcy polskich partii politycznych, „Preferencje Polityczne”, nr 2.

Turska-Kawa A. (2011), Osobowościowe predykatory zachowań wyborczych. Rozważania w kontekście modelu ,, wielkiej piqtki”, „Preferencje Polityczne”, nr 2.

Turska-Kawa A. (2013a), Tradycyjne i współczesne podejścia do procesu wyłaniania się przywództwa politycznego, „Athenaeum. Polskie Studia Politologiczne”, vol. 38 .

Turska-Kawa A. (2013b), Przywództwo polityczne jako wynik wzajemnej relacji między przywódcq a jego zwolennikami, ,Forum Politologiczne”, t. 15.

Urban M. (2001), Mechanizm legitymizacji przywódców politycznych w świetle teorii i praktyki marketingu politycznego, „Studia Politologiczne”, vol. 5.

Ustawa z dnia 20 czerwca 2002 roku o bezpośrednim wyborze wójta, burmistrza i prezydenta miasta, Dz. U. 2002, Nr 113, poz. 984 z późn. zm. 
Zaręba A. (2012), Wizerunek liderów partii politycznych na przykładzie kampanii parlamentarnej w 2011 roku, „Roczniki Nauk Społecznych”, t. 4, nr 3.

Żukiewicz P. (2012), O komunikacji w procesie przywództwa politycznego, „Lingua ac Communitas", vol. 22.

\section{New Dimension of Political Leadership: In Search of a New Perspective to Study the Personalization of Politics at a Local Level}

\section{Summary}

A politician's image is a specific kind of image shaped in the minds of voters which brings certain associations, thereby generating attitudes and having an impact on electoral preferences. The importance of personality traits and politicians' images as perceived by voters is increasing. Empirical studies into politicians' personalities continue to be among the most effective tools to examine the foundations for the personalization of politics also at a local level. These tools are to measure the personality traits of politicians as perceived by citizens. This paper attempts to systematize concepts, and introduces advanced empirical research.

Key words: personalization of politics, politician's image, local politics, political leadership 
